\title{
VULNERABILITY AND LIVELIHOOD RESILIENCE IN THE FACE OF NATURAL DISASTER: A CRITICAL CONCEPTUAL REVIEW
}

\author{
SARKER, M. N. I. ${ }^{1}$ - CAO, Q. ${ }^{1,2}-$ WU, M. $.^{1 *}-$ Hossin, M. A. ${ }^{3}-$ ALAM, G. M. M. ${ }^{4}-$ ShOUSE, R. C. ${ }^{1}$ \\ ${ }^{1}$ School of Public Administration, Sichuan University, Chengdu 610065, China \\ ${ }^{2}$ School of Economics and Management, Hubei MinZu University, Enshi 445000, China \\ ${ }^{3}$ Department of Information Management and E-commerce, University of Electronic Science \\ and Technology of China, Chengdu, China \\ ${ }^{4}$ Faculty of Agricultural Economics and Rural Development, Bangabandhu Sheikh Mujibur \\ Rahman Agricultural University, Gazipur, Bangladesh \\ *Corresponding author \\ e-mail:wuminhelen@163.com \\ (Received $3^{\text {rd }}$ May 2019; accepted $1^{\text {st }}$ Jul 2019)
}

\begin{abstract}
The concepts of vulnerability and resilience are gaining popularity in the development literature but still lack conceptual integration with the theory and practices of livelihood dynamics. However, the livelihood system of a community is a key element of the social system which may frequently be disrupted by the ecological, financial, natural and human-made vulnerability. Therefore, the purpose of this study is to clarify the concept of vulnerability and resilience in the perspective of livelihoods in a climate vulnerable context. It also addresses the methodological gaps through translation of theory from existing literature. This study argues that vulnerability and livelihood resilience are inversely related. It recommends some indicators and pillars for a better understanding of the vulnerability and livelihood resilience drawing from assorted literature through analysing the concept from various dimensions. The study will be helpful in understanding the livelihood dynamics and its assessment in the perspective of vulnerability and resilience.
\end{abstract}

Keywords: environmental management, security, climate change, adaptive capacity, environmental risk

\section{Introduction}

Vulnerability of people to possible natural hazards was impossible to measure before 1990s due to a lack of data availability, appropriate scales, and appropriate measurement approaches. Though according to Janssen (2006), the word 'vulnerability' appeared about 939 times in 2286 publications of disaster literatures in the last 30 years. Vulnerability to natural disasters is a combined effect of nature, environment, society, financial condition and community sensitivity. It is characterized by the susceptibility to be victimized or disrupted by natural disasters. Natural disasters, particularly climate change is a global concern and a daunting challenge for humanity since time immemorial. Natural disasters affect the livelihood of people of developing countries lacking in resources the most. So, natural disaster is one of the major causes of vulnerability (Dyakov, 2013; Garamvölgyi, 2013; Jamali et al., 2018; Sarker et al., 2019). The devastation of natural disasters occur in ways such as gradually changing average temperature, humidity and other environmental factors, increasing annual and seasonal climatic conditions, gradually increasing the frequency of hazardous events and the speed at which catastrophe factors are changing (Tompkins and Adger, 2004; IPCC, 2014; Omotoso et al., 2018; Nistor et al., 2018; Akhtar et al., 2019). 
Vulnerability is the ability of people, organization, and societies to withstand the adverse effects of stressors (Ajibade et al., 2013; Lee, 2014; Hoa, 2019; Terin, 2019). Most of the cases, the socio-ecological vulnerability of the people is the same across the globe. People usually faces three vulnerability components viz. exposure, sensitivity and adaptive capacity (Cutter et al., 2003; Fatemi et al., 2017). Comprehensive vulnerability analysis requires a specific context for better understanding. Vulnerability analysis should be done to find out the root causes and provide a suggestion for tackling adverse effect. Resilience is a concept which has been applied to research and practice in every possible field from science to sociology, nursing (Ho et al., 2012), medicine (Garcia-Dia et al., 2013), psychology, business and public administration. It is a process of "bounce back" or "returning to form" (Weldegebriel and Amphune, 2017). Livelihood resilience is the ability of an individual, group, or community to bounce back to anticipating livelihood challenges, reducing the effect of vulnerabilities, recovering effects from past and present vulnerabilities, and thriving even in a difficult livelihood environment (Gwimbi, 2009). This study is going to assess the status of livelihood resilience of riverine island dwellers and recommend some measures for improving their livelihood resilience.

The word 'resilience' originates from Latin word resilio that means 'to jump back' (Manyena, 2006). Walker and Salt (2012) have claimed that 'resilience' originated from ecological research where Holling (1973) sought to differentiate between an ecological system that persists in a condition of equilibrium or stability, and response of dynamic systems when they are stressed and move from this equilibrium. A resiliency perspective is an understanding of a system's adaptive capacity. For livelihood systems, the four pillars of this perspective relate to activities and processes allowing for effectively (a) anticipating livelihood challenges and potential for surprises (b) minimizing the impact of present vulnerabilities (c) recovering from the impact of past as well as present vulnerabilities and (d) thriving from a complex livelihood situation (Gwimbi, 2009).

Livelihood resilience is a top policy concept in development context research which emerging from various disciplines (Tanner et al., 2015). It actually focuses the ability of a community to bounce back to normal condition i.e. previous conditions after suffering shocks. Resilience is a process which tackles a wide range of shocks, vulnerability, and stress like vulnerable livelihood, food insecurity, social protection, disasters and social conflicts (Zebrowski, 2013). United Nations (2013) has already declared resilience as an important agenda for working as part of an integrated and comprehensive approach to assessing and addressing factors that undermine communities' and countries' resilience, including climate risk, environmental sustainability and social inequalities or exclusion. Natural disaster particularly climate change is a global concern and worst challenges for humanity from the ancient period. The main effect of natural disasters is on the livelihood of the resource poor people of developing countries.

Some studies have already been done on resilience in the psychology literature, climate change literature, engineering literature and social sciences (Dyakov, 2013; Garamvölgyi, 2013; Jamali et al., 2018; Alam et al., 2018; Sarker et al., 2019). Most of them focus on ecological analysis and few of them explain clearly about the concept of vulnerability and resilience in the perspective of a society which resulted to fill the connection with livelihood dynamics. Therefore, this study attempts to fill the research gap by addressing this issue through an extensive review of the literature. This study also intends to add the methodological implication for understanding and measuring the livelihood vulnerability of a community with the clarification of the concept. It also provides a new lens of the suitability and superiority of resilient livelihood thinking over sustainable livelihood framework (SLF) 
by exploring the weakness of SLF and adding solution for achieving livelihood resilience in a disaster vulnerability context. Though the term "resilience" is gaining popularity in the literature irrespective of the disciplines and livelihood research, the meaningful integration of the concept through proper translation from theories to action is really challenging. The concept of vulnerability and resilience is focused on the mainstream literatures such as climate change (Adger, 1999; Alam et al., 2018); disaster management (Shah et al., 2018; Adger, 2005), urban management (Sarker et al., 2019), nursing and engineering management (Fox-Lent and Linkov, 2018). But some researchers used the concepts for social-ecological system literature (Chaffin and Scown, 2018; Adger, 2005). The present study focuses the concept in the perspective of the socio-ecological system which is a better fit to livelihood system.

The rest of the paper is organized as section 2 deals with the methodology, section 3 describes the result of the study, section 4 deals with discussion focusing resilience and resilience concept emphasizing livelihood through developing a conceptual framework and final section concludes the article.

\section{Methodology}

\section{Research design}

A systematic literature review has been conducted for obtaining research objectives. An extensive desk literature review has been done for obtaining recent literature (from 2005 to 2018). Concept analysis has been done to clarify the resilience concept and validate the concept through filed data. A case study (as part of the author's PhD study) also has been done to validate the conceptual framework through assessing the vulnerability of disaster-prone community.

\section{Search strategy}

This study emphasizes the resilience concept in the multidisciplinary aspects. An extensive literature search has been done on some renowned databases like web of science, engineering village, and Scopus databases by using keywords such as "resilience, resilient, vulnerability, capacity" (Appendix A).

\section{Inclusion criteria}

The literature search is guided by two criteria; first, the study must focus on vulnerability and resilience; and second, livelihood is the main concern of the study. Livelihood resilience focused and peer reviewed articles have been considered for the time from 2005 to 2018 which focuses on human population. The focal points of the study are to identify the important definitive research on vulnerability and livelihood resilience, and the trend of the modification and integration of the concept and meaning of resilience to other discipline and its potential implication to the society.

\section{Exclusion criteria}

This study excludes the journal articles which have no full text, duplication and published in other languages than English. It also excludes the articles in which content does not cover the concept of resilience and disaster vulnerability context. 


\section{Review results}

Preferred Reporting Items for Systematic Review and Meta-Analysis (PRISMA) guidelines has been followed in a systematic literature review (Moher et al., 2009). The review search has been done by following several steps; first, 575 documents are identified with 19 from references (Fig. 1). After removing the duplicates, 254 documents have been selected by abstract screening. Then 116 documents have been excluded due to lack of full text, irrelevant, not focusing on livelihood resilience. Finally, 29 documents have been selected from journal articles, books, book chapters, and working papers (Appendix B). The checklist of the Reporting of Observational Studies in Epidemiology (STROBE) is also followed for qualitative document selection (Vandenbroucke et al., 2007). This review has been conducted from December 2018 to January 2019. A conceptual model has been developed for livelihood resilience.

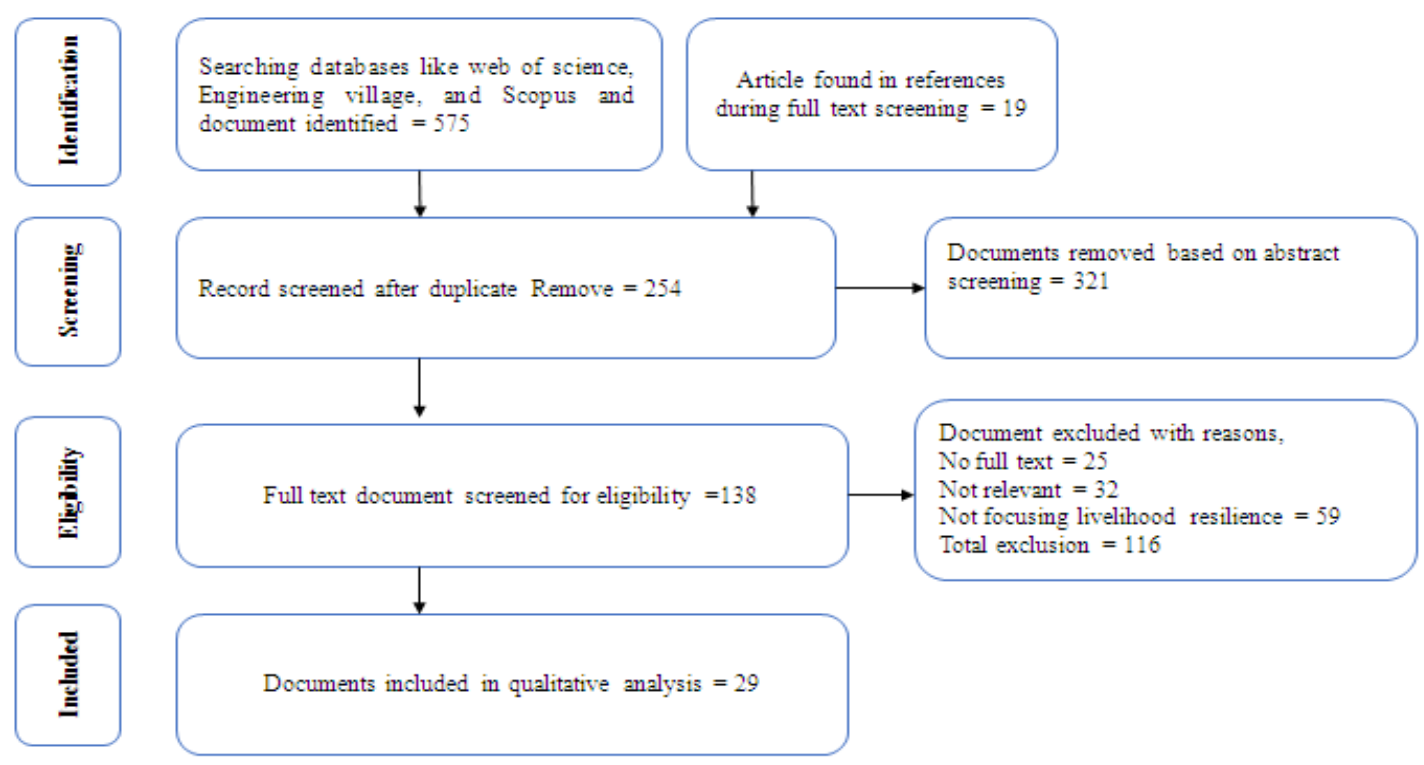

Figure 1. PRISMA selection for qualitative study

\section{Discussion}

The findings of this study have been presented into two following sub-sections; the first section deals with vulnerability and second section deals with livelihood resilience.

\section{Vulnerability}

\section{The concept of vulnerability}

The major characteristics of vulnerability are its dynamic nature that influences people's social and biophysical processes (IPCC, 2014). Significant attention is needed from the researchers and policymakers to develop successful adaptation strategies. Citizens of developing countries are highly vulnerable due to low income and dependency on agriculture (UNDP, 2008). These burdens should spark exploration of potential adaptive capacities for resource poor communities. People's susceptibility to the impact vulnerability of natural hazards are increasing to almost all spheres of life like social physical, human, financial, and natural dimensions. Though the effect of 
natural hazards may be occasional, seasonal or year-round, the extent of exposure varies across communities.

Rural livelihood is highly dependent on climatic variability as its dependence on agriculture. Livelihood vulnerability means the susceptibility of livelihood system of stressors. Since the livelihood system of a community comprises natural, human, social, physical and financial capitals that mean it solely depends on the socio-ecological system. According to DasGupta and Shaw (2015), rural livelihood is adversely affected by the effect of climate change. Abid et al. (2016) mention that rural livelihood is dependent on a complex system of institutional, biophysical, financial and political condition of the community. Livelihood vulnerability actually focuses the exposure, sensitivity as well as adaptive capacity of an individual's livelihood or a community's livelihood in the face of natural disasters.

\section{Dimensions of vulnerability}

The major three components of livelihood vulnerability are exposure, sensitivity and adaptive capacity (Fig. 2). Exposure addresses the extent of a system facing varying climate conditions. It generally focuses the condition of an individual or community during facing variable climatic situations. It shows the frequency, and extent of loss in terms of livelihood capitals. Sensitivity means the degree of a system which addresses how sensitive to the variable climatic conditions. It generally focuses the reaction of an individual or community during facing changing climatic situations. It also shows the frequency, and sensitiveness in terms of livelihood capitals. Adaptive capacity is the ability of a system to withstand against the stressors and shocks. It emphasizes the ability of an individual or a society to tackle or control the situation which occurs during natural hazards.

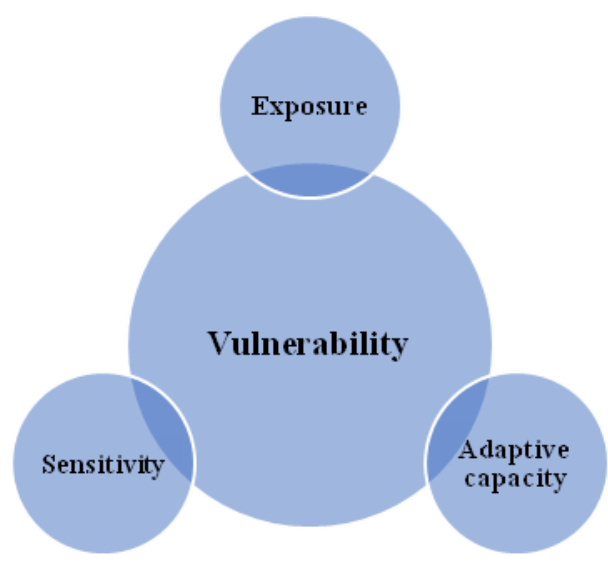

Figure 2. The major elements of vulnerability in a socio-ecological system

Vulnerability of the people of developing countries is almost similar all over the world such as flooding, riverbank erosion, drought, storm, cyclone, crop and livestock diseases infestation. Paavola (2008) conducted a study on livelihood vulnerability of Tanzanian farmers and reported that agricultural farming-based livelihood is highly vulnerable to climatic variability. Livelihood system is varied from community to community such as livelihood of the people of rural Burkin Faso is solely dependent crop cultivation, livestock and agroforestry and they suffer from seasonal food 
insecurity due to climatic variability (Addisu et al., 2016). Jacobi conducted a study on the livelihood of the fish farming community in Kenya and reported that climatic variability was the main drivers of vulnerability to the community. Beckford and Rhiney (2016) assess the vulnerability of a community living in north eastern St Vincent and concluded that the main driver of poverty was livelihood vulnerability caused by environmental variability and globalization. Climate change is one of the main drivers of livelihood vulnerability of the people of coastal areas especially natural resources dependent people. Chinwendu et al. (2017) conducted a study on household vulnerability and adaptation to climate change in Kaduna river basin in Nigeria and reported that livelihood vulnerability was varied from village to village of riverbank community due to varies of sensitivity to risk, uncertainty and limited access to natural resources and institutional capacity. Antwi et al. (2015) assessed the community vulnerability of a flood prone community in Ghana and mentioned that climate induced disasters make the people vulnerable in terms of socio-ecological, financial and political aspects.

Natural disasters are the outcome of interaction among hazard and stake, living and non-living and fixed and moving elements which causes human, economic, environmental, socio-political losses and cultural crisis in people's livelihood. Most of the rural communities have faced vulnerabilities in terms of various livelihood capitals such as social, political, financial and natural assets due to dynamic changes of environment in Zimbabwe (Nyamwanza, 2012). Wilson (2014) conducted a study on livelihood vulnerability and politics of adaptation in Alaska and reported that subsistence livelihood of the people was highly vulnerable due to climate change impact which could be minimized through developing context specific adaptation strategies. Literature across the world shows that changing climate is the main driver of livelihood vulnerability which affects almost all aspects of human life.

\section{Livelihood resilience}

\section{The concept of livelihood resilience}

Livelihood is a way of living which is comprised of the capabilities, assets, and activities. Livelihood resilience is the ability of a people or a community to sustain and retain livelihood opportunities in a stress situation which caused by the disturbances of social-ecological system, political system, and financial reasons. Resilience is a set of behaviors that stimulate social transformation and empower a group of people or social system (Earvolino-Ramirez, 2007; Gaillard, 2010; Jorgenson et al., 2010; Scholz et al., 2012). Livelihood resilience integrates livelihood system with resilience in a way where people are the main actors in the adaptation practices. The environmental factors are responsible for hampering the livelihood system of resource poor and vulnerable people to conduct their daily life (Adger, 1999). It thus requires an in-depth investigation of how climatic factors influence the livelihoods of people. Though sustainable livelihood framework is developed for the use of international agencies for poverty alleviation through improving livelihood assets, it adds a new dimension for livelihood research especially for the livelihoods which associated with the vulnerability, shocks, and stress of social and ecological systems (Vogel et al., 2007; Zebrowski, 2013). Importantly, people are the central concern of livelihood thinking where ecological factors, social and political factors, market, technology and resources are the associated factors related to livelihood (Panthi et al., 2016). 
Livelihood resilience however, stimulates the capacities of an individual, community or administrative system to respond to the challenges, risks, stressors and disturbances. It also enables people to perceive the risks and uncertainties of social-ecological systems and to take anticipatory actions to tackle the adverse situation. An ideal resilience system requires natural resources, information and access to physical, economic and logistic assets for developing the system against the disturbances of the environment. Livelihood resilience also integrates social networks with human rights for resilience thinking. Both human rights and social network are essential elements of social system to develop the capacity of the system against any adverse situation.

\section{Livelihood resilience thinking from sustainable livelihood framework}

The present study borrows the concept of ecological resilience for livelihood inquiry for better explanation of livelihood resilience in the disaster vulnerability context. The other concept of resilience is indirectly related to livelihood system because of its relation to the changing climate, stress and shocks as well as physical infrastructure, social and economic system and institutional responses. Since ecological system is completely different from livelihood system, this study considers all related dimensions of social and ecological systems for better integration of livelihood inquiry to resilience. A sustainable livelihood approach is followed to assess the livelihood pattern which consists of the analysis in the context of people's livelihood. This approach confirms Sen's (1981) classic focus entitlement, Long's (1984) action oriented approach, and Chambers and Conway's (1992) seminal paper on sustainable livelihood. Sustainable livelihood approach is a well-accepted approach which has emerged in 1990s for assessing the livelihood system and strategies in the face of natural disasters and vulnerability of rural people. According to sustainable livelihood approach (following Chambers and Conway, 1992; Scoones, 1998), livelihood is a set of physical and social assets, and actions for living as well as it can be sustainable in such a condition when it is able to cope with and retain from risk, uncertainty and stress through enhancing capabilities and without hampering the natural resources.

The sustainable livelihood approach considers demographic, socio-economic, political and ecological context of people's life and access to social, economic, physical, natural and human capitals as well as institutional aspects for ensuring people's access and control over assets. Various scholars developed some analytical framework by using the diagrammatic checklist developed by Scoones (1998) such as vulnerability framework by Moser (1998), capitals and capability framework of Bebbington (1999) and micro-policy analytical framework by Ellis (2000). Using the principles of sustainable livelihood framework, some renowned organization already developed their operational SLF such as Cooperative for Assistance and Relief Everywhere (CARE), Department for International Development (DFID), Oxfam and the United Nations Development Program (UNDP). Since various organization developed their livelihood analysis framework in the light of SLF, this study only considers SLF for guiding own research direction.

There is an increasing trend of using the sustainable livelihood framework in assessing vulnerability, risk, uncertainty and livelihood literatures (for example, Can et al., 2013; Amos, et al., 2015; Addisu et al., 2016; Alam, 2016; Bhuiyan et al., 2017) all over the world. Sustainable livelihood framework (SLF) is a basis of rural vulnerability studies irrespective of the country (for example Li et al., 2018; Pandey et al., 2017). Theoretically, the sustainable livelihood framework (SLF) is developed to deal with 
condition where the poor perform as 'strategic managers' in transferring the livelihoods outcomes, through a set of livelihood activities in accordance with the entitlements and access to resources, as decided by the conditions of institutional contexts (Moser, 1998). The sustainable frameworks point to assets as central concern which is mainly affected by the environmental stressors. Livelihood strategies and institutional process are the driver for transforming the vulnerable context to sustainable livelihood. Livelihood strategies are the strategies taken by the people for maintaining their livelihood and institutional process is responsible for translating the assets and strategies into action for making desirable and sustainable changes in people's livelihood. The major livelihood strategies of rural people are agricultural practices, diversification of livelihood, and migration (Ellis, 2008).

The SLF approach may be explained in three ways; first, framework for short-term livelihood trajectories; second, a way of development activities; and third, outline of overall development. In the livelihood related literature, the SLF was possibly envisioned as the earlier; as "a diagram to organize ideas into manageable categories, to identify entry points and critical processes, and assist with prioritizing catalysts for change that can improve people's livelihoods" (Ellis, 2000).

\section{Strength of sustainable livelihood framework}

Vulnerability assessment requires understanding of the SLF in terms of its strengths and weakness for building a concrete method of assessment (Pandey et al., 2017). Due to its strength, it is well accepted all over the world for livelihood assessment. The main strengths of SLF are focusing people-centeredness, people's capabilities and holisticness. First, SLF is people-centered approach which focuses people's realities, strengths and compromises to others. It emphasizes local complexities and realities for analyzing the issues in a better way. Second, SLF analyzes people's capabilities and strengths which is necessary for overcoming risk, uncertainty and livelihood insecurity (Ekblom, 2012). Third, SLF is a holistic in nature in terms of its recognition to multiple strategies, actors and outcomes where people's livelihood is connected. So, it is applicable to assess the dynamics of livelihood vulnerability of char dwellers in Bangladesh. Sustainable livelihood framework has broad aspects of inquiry covering vulnerability, shocks, risks, assets, institutional response, strategies of livelihood and outcomes which may be a toolkit for livelihood analysis. According to Clark and Carney (2008), SLF is a key analytical tool to assess and understand various aspects of the livelihood of people.

\section{Weakness of sustainable livelihood framework}

Though SLF is well accepted by various scholar but it is still criticized due to ignoring or avoiding some important issues. The main limitation of SLF is its inability to address the social, political, and institutional aspects (Scoones, 2009). It actually avoids focusing the role of structures, acting process, and institutions rather emphasizing assets and activities of household though the assets are not neutral due to its inclusion and exclusion nature (Antwi et al., 2015). SLF generally assess the livelihood status at household level which is a key to local context but less concentration to connect with national and global level. Livelihood vulnerability analysis requires an emphasize on a connection with institutional levels for better integration with the institutional capital irrespective of micro or macro level 
perspectives. An importance on institutional process and political economy focusing structural forces is necessary to assess the dynamic of rural livelihoods and resilience (Scoones, 2009) but present form of SLF cannot meet this issue. Besides the term "sustainable," a core term of SLF, has not been properly focused in terms of variable local context (Bhattacharjee and Behera, 2018).

SLF cannot provide the answers to some quires such as 'sustainable to what and for whom' whose reality to be addressed? (Chambers and Conway, 1992) which are very much important in dynamic vulnerability context. According to Longley and Maxwell (2013), SLF is very much developed and applicable only for reducing poverty in relatively stable context. One of the major weak points of SLF is how to address sustainability in the dynamic vulnerability context where livelihood assets are recurrently hampered with environmental factors. SLF is basically outcome-based approach which cannot address the related process and capacities. It focuses only on short-term dynamics rather than long term which reduce the ability to address the dynamic vulnerability context of livelihood.

\section{From sustainable livelihoods to resilient livelihoods thinking}

This study attempts to develop a framework for addressing the weakness of SLF and assess the dynamic context of vulnerability and livelihood through including elements of adaptive, absorptive and transformative capacity. Resilience thinking is the advanced option of livelihood vulnerability assessment following SLF but addressing all weakness of SFL. This study adopted SLF for operationalization of the perspective of resiliency using the useful idea from SLF for better understanding the dynamic vulnerable context. The transformation from sustainable livelihood to resilient livelihood is summarized and presented in Table 1.

Table 1. Summarizing main aspects on shifts from sustainable to resilient livelihoods thinking (Source: adapted after Nyamwanza, 2012)

\begin{tabular}{c|c}
\hline Sustainable livelihoods thinking & Resilient livelihoods thinking \\
\hline Sustainability & $\begin{array}{c}\text { Resiliency by adaptive, absorptive and } \\
\text { transformative capacity }\end{array}$ \\
\hline Assets & Institutions and assets \\
\hline Linking household and geographical/spatial scales & $\begin{array}{c}\text { Linking institution, community, household and } \\
\text { temporal scales }\end{array}$ \\
\hline Coping and short-term dynamics & $\begin{array}{c}\text { Both coping and adapting - however focusing more } \\
\text { on long-term adaptation dynamics }\end{array}$ \\
\hline Outcome-oriented & Process-oriented \\
\hline
\end{tabular}

It is well established that the core ideas of sustainable livelihood framework form the central position of the analysis of dynamic vulnerability context. In this study, resilient livelihood thinking is focused on using the useful ideas from sustainable livelihoods for better understanding the dynamics of changing vulnerability context. The resiliency perspective as advanced in this work builds on the strengths of this thinking, blending it with new ideas in taking livelihood analysis forward - from thinking about 'sustainable' livelihoods to 'resilient' livelihoods. Ideas from Scoones's (1998) 'diagrammatic checklist' and Ellis's (2000) livelihoods framework were used in the adapted framework to guide analysis. This is because while showing general interrelationships and 
connections, these scholars' presentations provide room for re-arranging ideas and infusing new ones as they seem less rigidly formulated to show particular linear or contextual patterns. Table 1 summarizes the major aspects vis-à-vis shifts from sustainable livelihoods to resilient livelihood thinking as raised in various discussions in this work so far.

The conceptual framework (Fig. 3) has been developed by following 'diagrammatic checklist' of Scoones (1998), livelihood framework of Ellis (2000) and livelihood framework for resilience of Nyamwanza (2012). This selection is due to the flexibility of their framework to include element, re-arranging ideas and developing new one for context specific livelihood analysis. The conceptual framework focuses vulnerability context (flood, drought, riverbank erosion, cyclones, shocks, and risks), livelihood assets (human, natural, social, physical and financial assets), institutions (household, community, sub-national, and national level), adaptive strategies (livelihood strategies), various capacities (adaptive, absorptive, and transformative capacity) and outcome related livelihood.

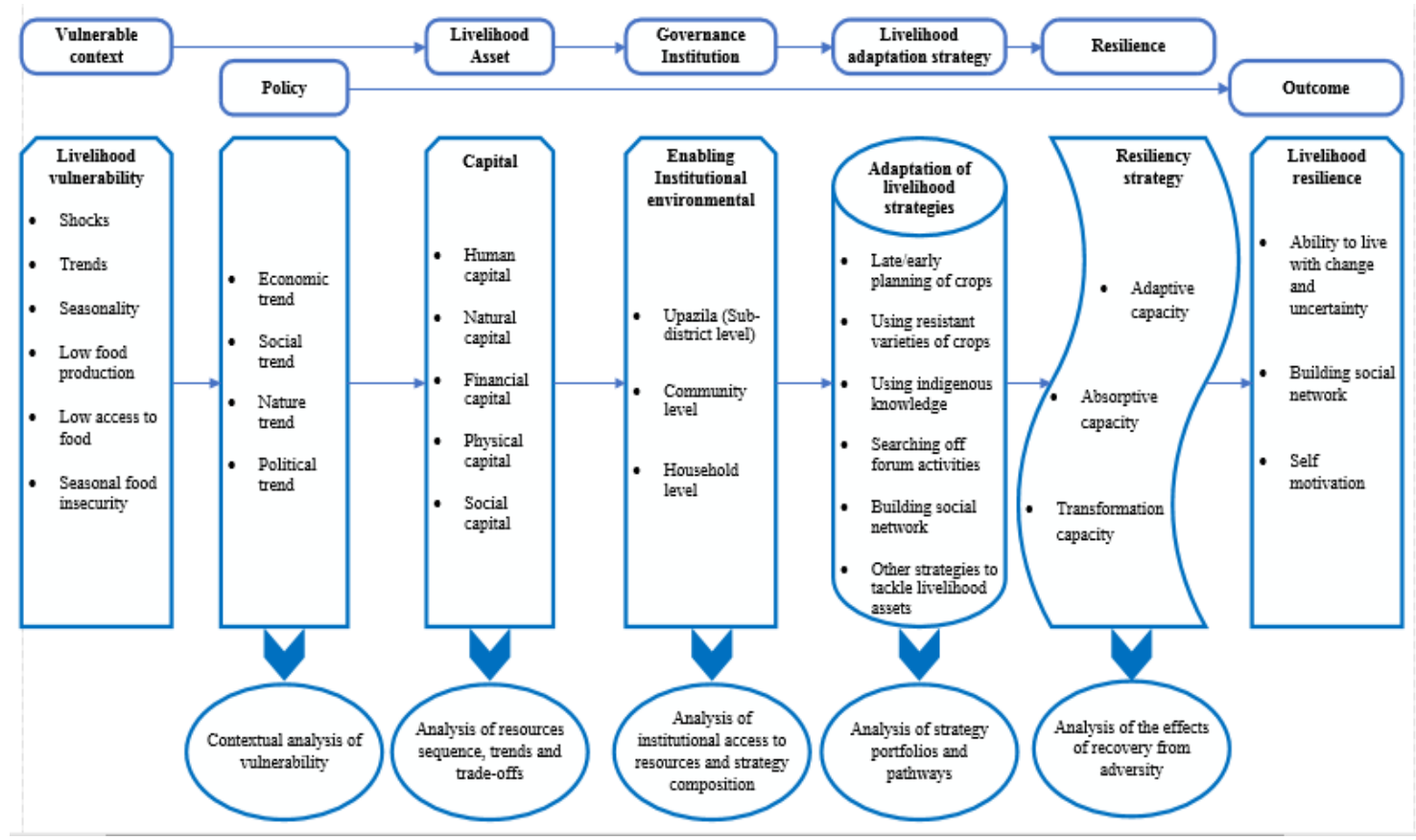

Figure 3. Adapted livelihood framework for resilience (Source: adapted after Scoones, 1998; Ellis, 2000; Nyamwanza, 2012)

The framework will be applicable to analyze the vulnerability of any community especially who are facing the adverse of climate change. It will help to interpret the factors responsible for livelihood vulnerability, and the positive effect of policy measures and livelihood assets to overcome the vulnerable condition. It also provides the direction of how government institution can solve and improve the vulnerability context and which level is most suitable for government intervention. This framework might be useful for its adaptation strategies for improving livelihood condition in a vulnerability context. It also focuses how resilience capacities developed and work in a vulnerable livelihood context for obtaining a self-motivation, strong social network and ability to live with uncertainty. 


\section{Conclusion}

The concept of livelihood resilience is relatively new in natural disaster vulnerability context. This study attempts to clarify the livelihood resilience concept from the perspective of climate change vulnerability and natural disasters. It analyzes the resilience concept by focusing on various dimensions of vulnerability and resilience. It also integrates the livelihood system to the resilience concept successfully through analyzing more related existing literature of the renowned databases. This study reveals that vulnerability is a function of exposure, sensitivity and adaptive capacity of a system in which exposure and sensitivity are positively related to vulnerability while adaptive capacity is negatively related. Similarly, livelihood resilience is a function of the adaptive, absorptive and transformative capacity of livelihood system which enables people to sustain and retain livelihood opportunities in stress events caused by natural disasters. Livelihood capitals (e.g. social, natural, human, physical and financial capital) help to enhance the capacity of the people in the face of climate change vulnerability. This study also interprets the development of resilient livelihood thinking from traditional sustainable livelihood framework which is suffering from various weaknesses. This study argues that livelihood resilience is more advanced and suitable approach to address disaster related vulnerability issues. This study further argues that resilience livelihood framework and related indicators will help to assess the vulnerability of a socio-ecological system and to take proper measure to improve livelihood resilience of any vulnerable people, group or community. The study suggests conducting in-depth empirical study on livelihood resilience assessment in the natural disaster prone vulnerability context using specific indicators developed in this study for future research.

Acknowledgements. This article is funded by Management Science and National Governance Disciplines Platform of Sichuan University, Sichuan University Innovation Spark Project (No.2018hhs21), Sichuan University Central University Basic Scientific Research Project (No.skqx201501).

\section{REFERENCES}

[1] Abid, M., Schilling, J., Scheffran, J., Zulfiqar, F. (2016): Climate change vulnerability, adaptation and risk perceptions at farm level in Punjab, Pakistan. - Science of the Total Environment 547: 447-460. https://doi.org/10.1016/j.scitotenv.2015.11.125.

[2] Addisu, L. S., Olutayo, O. A., Sulaiman, H., Rao, P. (2016a): Assessing climate change impacts in the Lake Tana Sub-Basin, Ethiopia using livelihood vulnerability approach. - Journal of Earth Science Climatic Change 7(9): https://doi.org/10.4172/21577617.1000368 .

[3] Addisu, S., Fissha, G., Gediff, B., Asmelash, Y. (2016a): Perception and adaptation models of climate change by the rural people of lake Tana Sub-Basin, Ethiopia. Environmental Systems Research 5(1): 7. https://doi.org/10.1186/s40068-016-0059-0.

[4] Adger, W. N. (1999): Social vulnerability to climate change and extremes in coastal Vietnam. - World Development 27(2): 249-269. https://doi.org/10.1016/S0305750X(98)00136-3.

[5] Adger, W. N. (2005): Social-ecological resilience to coastal disasters. - Science 309(5737): 1036-1039. https://doi.org/10.1126/science.1112122.

[6] Ajibade, I., McBean, G., Bezner-Kerr, R. (2013): Urban flooding in Lagos, Nigeria: patterns of vulnerability and resilience among women. - Global Environmental Change 23(6): 1714-1725. https://doi.org/10.1016/j.gloenvcha.2013.08.009. 
[7] Akhtar, N., Saqib, Z., Khan, M. I., Martin, M. A., Atif, S. B., Zaman, M. H. (2019): A bibliometric analysis of contemporary research regarding industrial symbiosis: a path towards urban environmental resilience. - Applied Ecology and Environmental Research 17(1): 1159-1221. https://doi.org/10.15666/aeer/1701_11591221.

[8] Alam, G. M. M. (2016): An assessment of the livelihood vulnerability of the riverbank erosion hazard and its impact on food security for rural households in Bangladesh. $\mathrm{PhD}$ Dissertation, University of Southern Queensland, Toowoomba, Australia.

[9] Alam, G. M. M., Alam, K., Mushtaq, S., Filho, W. L. (2018): How do climate change and associated hazards impact on the resilience of riparian rural communities in Bangladesh? Policy implications for livelihood development. - Environmental Science Policy 84: 7-18. https://doi.org/10.1016/j.envsci.2018.02.012.

[10] Amos, E., Akpan, U., Ogunjobi, K. (2015): Households' perception and livelihood vulnerability to climate change in a coastal area of Akwa Ibom State, Nigeria. Environment, Development and Sustainability 17(4): 887-908. https://doi.org/10.1007/s10668-014-9580-3.

[11] Antwi, E. K., Boakye-Danquah, J., Barima Owusu, A., Loh, S. K., Mensah, R., Boafo, Y. A., Apronti, P. T. (2015): Community vulnerability assessment index for flood prone savannah agro-ecological zone: a case study of Wa West District, Ghana. - Weather and Climate Extremes 10: 56-69. https://doi.org/10.1016/j.wace.2015.10.008.

[12] Bebbington, A. (1999): Capitals and capabilities: A Framework for Analyzing Peasant Viability, Rural Livelihoods and Poverty. - World Development 27(12): 2021-2044. https://doi.org/10.1016/S0305-750X(99)00104-7.

[13] Beckford, C. L., Rhiney, K. (2016): Globalization, Agriculture and Food in the Caribbean. - In: Beckford, C. L., Rhiney, K. (eds.) Globalization, Agriculture and Food in the Caribbean: Climate Change, Gender and Geography. Palgrave Macmillan, London. https://doi.org/10.1057/978-1-137-53837-6.

[14] Bhattacharjee, K., Behera, B. (2018): Determinants of household vulnerability and adaptation to floods: empirical evidence from the Indian State of West Bengal. International Journal of Disaster Risk Reduction 31: 758-769. https://doi.org/10.1016/j.ijdrr.2018.07.017.

[15] Bhuiyan, M. A. H., Islam, S. M. D.-U., Azam, G. (2017): Exploring impacts and livelihood vulnerability of riverbank erosion hazard among rural household along the river Padma of Bangladesh. - Environmental Systems Research 6(1): 25. https://doi.org/10.1186/s40068-017-0102-9.

[16] Can, N. D., Tu, V. H., Hoanh, C. T. (2013): Application of livelihood vulnerability index to assess risks from flood vulnerability and climate variability - a case study in the Mekong Delta of Vietnam. - Journal of Environmental Science and Engineering 2: 476-486.

[17] Chaffin, B. C., Scown, M. (2018): Social-ecological resilience and geomorphic systems. $\quad-\quad$ Geomorphology https://doi.org/10.1016/j.geomorph.2017.09.038.

[18] Chambers, R., Conway, G. R. (1992): Sustainable Rural Livelihoods: Practical Concepts for the $21^{\text {st }}$ Century. - Institute of Development Studies, UK.

[19] Chinwendu, O. G., Sadiku, S. O. E., Okhimamhe, A. O., Eichie, J. (2017): Households vulnerability and adaptation to climate variability induced water stress on downstream Kaduna River Basin. - American Journal of Climate Change 6(02): 247-267. https://doi.org/10.4236/ajcc.2017.62013.

[20] Clarke, J., Carney, D. (2008): Sustainable livelihoods approaches - what have we learned? - Background paper for ESRC Livelihoods Seminar, Institute of Development Studies, Brighton. https://doi.org/10.3362/0262-8104.2002.002.

[21] Cutter, S. L., Boruff, B. J., Shirley, W. L. (2003): Social vulnerability to environmental hazards. - Social Science Quarterly 84(2): 242-261. https://doi.org/10.1111/15406237.8402002 . 
[22] DasGupta, R., Shaw, R. (2015): An indicator based approach to assess coastal communities' resilience against climate related disasters in Indian Sundarbans. Journal of Coastal Conservation 19(1): 85-101. https://doi.org/10.1007/s11852-0140369-1.

[23] Dyakov, N. (2013): Alien species invasion and diversity of riparian forest according to environmental gradients and disturbance regime. - Applied Ecology and Environmental Research 11(2): 249-272. https://doi.org/10.15666/aeer/1102_249272.

[24] Earvolino-Ramirez, M. (2007): Resilience: a concept analysis. - Nursing Forum 42(2): 73-82. https://doi.org/10.1111/j.1744-6198.2007.00070.x.

[25] Ekblom, A. (2012): Livelihood security, vulnerability and resilience: a historical analysis of Chibuene, Southern Mozambique. - Ambio 41(5): 479-489. https://doi.org/10.1007/s13280-012-0286-1.

[26] Ellis, F. (2000): Rural Livelihoods and Diversity in Developing Countries. - Oxford University Press, Oxford, pp. 1-256.

[27] Ellis, F. (2008): The determinants of rural livelihood diversification in developing countries. - Journal of Agricultural Economics 51(2): 289-302. https://doi.org/10.1111/j.1477-9552.2000.tb01229.x.

[28] Fatemi, F., Ardalan, A., Aguirre, B., Mansouri, N., Mohammadfam, I. (2017): Social vulnerability indicators in disasters: findings from a systematic review. - International $\begin{array}{lllll}\text { Journal of Disaster Risk Reduction 22: 219-227. } & \text { 22 }\end{array}$ https://doi.org/10.1016/j.ijdrr.2016.09.006.

[29] Fox-Lent, C., Linkov, I. (2018): Resilience matrix for comprehensive urban resilience planning. - Lecture Notes in Energy 65: 29-47. https://doi.org/10.1007/978-3-31975798-8_2.

[30] Gaillard, J. C. (2010): Vulnerability, capacity and resilience: perspectives for climate and development policy. - Journal of International Development 22(2): 218-232. https://doi.org/10.1002/jid.1675.

[31] Garamvölgyi, Á. (2013): Impacts of climate change on vegetation distribution no. 1 -climate change induced vegetation shifts in the palearctic region. - Applied Ecology $\begin{array}{llll}\text { and } & \text { Environmental } & \text { 79-122. }\end{array}$ https://doi.org/10.15666/aeer/1101_079122.

[32] Garcia-Dia, M. J., DiNapoli, J. M., Garcia-Ona, L., Jakubowski, R., O'Flaherty, D. (2013): Concept analysis: resilience. - Archives of Psychiatric Nursing 27(6): 264-270. https://doi.org/10.1016/j.apnu.2013.07.003.

[33] Gwimbi, P. (2009): Linking rural community livelihoods to resilience building in flood risk reduction in Zimbabwe. - Jàmbá: Journal of Disaster Risk Studies 2(1): 71-89. https://doi.org/10.4102/jamba.v2i1.16.

[34] Ho, H. Y., Lee, Y. L., Hu, W. Y. (2012): Elder resilience: a concept analysis. - Journal of Nursing 59(2): 88-92. https://doi.org/10.1111/j.1744-6198.2007.00070.x.

[35] Hoa, A. X. (2019): Advancing smallholders' sustainable livelihood through linkages among stakeholders in the Cassava (Manihot Esculenta Crantz) value chain: the case of Dak Lak province, Vietnam. - Applied Ecology and Environmental Research 17(2): 5193-5217. https://doi.org/10.15666/aeer/1702_51935217.

[36] Holling, C. S. (1973): Resilience and stability of ecological systems. - Annual Review $\begin{array}{lllll}\text { of } \text { Ecology } & \text { 1-23. }\end{array}$ https://doi.org/10.1146/annurev.es.04.110173.000245.

[37] Sarker, M. N. I., Wu, M., Shouse, R. C., Ma, C. (2019): Administrative Resilience and Adaptive Capacity of Administrative System: A Critical Conceptual Review. - In: Xu, J. et al. (ed.) Lecture Notes on Multidisciplinary Industrial Engineering. Springer, Switzerland, pp. 1-13. https://doi.org/10.1007/978-3-030-21255-1_55.

[38] IPCC (2014): Climate change 2014: Impacts, adaptation and vulnerability. Fifth assessment report. - In: Intergovernmental Panel on Climate Change. - Cambridge University Press, Cambridge, UK. 
[39] Jamali, A. A., Zarekia, S., Randhir, T. O. (2018): Risk assessment of sand dune disaster in relation to geomorphic properties and vulnerability in the Saduq-Yazd Erg. Applied Ecology and Environmental Research 16(1): 579-590. https://doi.org/10.15666/aeer/1601_579590.

[40] Janssen, M. A., Schoon, M. L., Ke, W., Börner, K. (2006): Scholarly networks on resilience, vulnerability and adaptation within the human dimensions of global environmental change. - Global Environmental Change 16(3): 240-252. https://doi.org/10.1016/j.gloenvcha.2006.04.001.

[41] Jorgenson, M. T., Romanovsky, V., Harden, J., Shur, Y., O’Donnell, J., Schuur, E. A. G., ... Marchenko, S. (2010): Resilience and vulnerability of permafrost to climate change. - Canadian Journal of Forest Research 40(7): 1219-1236. https://doi.org/10.1139/X10-060.

[42] Lee, Y. J. (2014): Social vulnerability indicators as a sustainable planning tool. Environmental Impact Assessment Review 44: 31-42. https://doi.org/10.1016/j.eiar.2013.08.002.

[43] Li, C., Wang, M., Song, Y. (2018): Vulnerability and livelihood restoration of landless households after land acquisition: evidence from peri-urban China. - Habitat International 79: 109-115. https://doi.org/10.1016/j.habitatint.2018.08.003.

[44] Long, N. (1984): Family and Work in Rural Societies-Perspectives on Non-Wage Labour. - Tavistock, London.

[45] Longley, C., Maxwell, D. (2013): Livelihoods, Chronic conflict and humanitarian response: a synthesis of current practice (No. 182). - ODI Working Paper, London SE3 7JD, UK.

[46] Manyena, S. B. (2006): Rural local authorities and disaster resilience in Zimbabwe. Disaster Prevention and Management: An International Journal 15(5): 810-820. https://doi.org/10.1108/09653560610712757.

[47] Moher, D., Liberati, A., Tetzlaff, J., Altman, D. G., Altman, D., Antes, G., ... Tugwell, P. (2009): Preferred reporting items for systematic reviews and meta-analyses: the PRISMA statement. $\quad-\quad$ PLoS Medicine 6(7): 1-5. https://doi.org/10.1371/journal.pmed.1000097.

[48] Moser, C. O. N. (1998): The asset vulnerability framework: reassessing urban poverty reduction strategies. - World Development 26(1): 1-19. https://doi.org/10.1016/S0305750X(97)10015-8.

[49] Nistor, M. M., Nicula, A. S., Cervi, F., Man, T. C., Irimuş, I. A., Surdu, I. (2018): Groundwater vulnerability GIS models in the Carpathian mountains under climate and land cover changes. - Applied Ecology and Environmental Research 16(4): 5095-5116. https://doi.org/10.15666/aeer/1604_50955116.

[50] Nyamwanza, A. M. (2012): Resiliency and Livelihoods Inquiry in Dynamic Vulnerability Contexts: Insights from Northern Zimbabwe. - The University of Manchester, UK.

[51] Omotoso, A. B., Daud, A. S., Adebayo, R. A., Omotayo, A. O. (2018): Socioeconomic determinants of rural households'food crop production in Ogun state, Nigeria. Applied Ecology and Environmental Research 16(3): 3627-3635. https://doi.org/10.15666/aeer/1603_36273635.

[52] Paavola, J. (2008): Livelihoods, vulnerability and adaptation to climate change in Morogoro, Tanzania. - Environmental Science Policy 11(7): 642-654. https://doi.org/10.1016/j.envsci.2008.06.002.

[53] Pandey, R., Jha, S. K., Alatalo, J. M., Archie, K. M., Gupta, A. K. (2017): Sustainable livelihood framework-based indicators for assessing climate change vulnerability and adaptation for Himalayan communities. - Ecological Indicators 79: 338-346. https://doi.org/10.1016/j.ecolind.2017.03.047.

[54] Panthi, J., Aryal, S., Dahal, P., Bhandari, P., Krakauer, N. Y., Pandey, V. P. (2016): Livelihood vulnerability approach to assessing climate change impacts on mixed agro- 
livestock smallholders around the Gandaki River Basin in Nepal. - Regional Environmental Change 16(4): 1121-1132. https://doi.org/10.1007/s10113-015-0833-y.

[55] Sarker, M. N. I., Wu, M., Alam, G. M. M., Shouse, R. C. (2019): Livelihood vulnerability of riverine-island dwellers in the face of natural disasters in Bangladesh. Sustainability 11(6): 1623. https://doi.org/10.3390/su11061623.

[56] Scholz, R. W., Blumer, Y. B., Brand, F. S. (2012): Risk, vulnerability, robustness, and resilience from a decision-theoretic perspective. - Journal of Risk Research 15(3): 313330. https://doi.org/10.1080/13669877.2011.634522.

[57] Scoones, I. (1998): Sustainable rural livelihoods: a framework for analysis. - IDS Working Paper (No. 72). https://doi.org/10.1057/palgrave.development.1110037.

[58] Scoones, I. (2009): Livelihoods perspectives and rural development. - The Journal of Peasant Studies 36(1): 37-41. https://doi.org/10.1080/03066150902820503.

[59] Sen, A. (1981): Poverty and Famines. - Clarendon Press, Oxford, UK. https://doi.org/10.1086/451432.

[60] Shah, A. A., Ye, J., Abid, M., Khan, J., Amir, S. M. (2018): Flood hazards: household vulnerability and resilience in disaster-prone districts of Khyber Pakhtunkhwa province, Pakistan. - Natural Hazards 93(1): 147-165. https://doi.org/10.1007/s11069-018-32930 .

[61] Tanner, T., Lewis, D., Wrathall, D., Bronen, R., Cradock-Henry, N., Huq, S., ... Thomalla, F. (2015): Livelihood resilience in the face of climate change. - Nature Climate Change 5(1): 23-26. https://doi.org/10.1038/nclimate2431.

[62] Terin, M. (2019): Determining factors in food away from home expenditure of Turkish households. - Applied Ecology and Environmental Research 17(2): 3441-3455. https://doi.org/10.15666/aeer/1702_34413455.

[63] Tompkins, E. L., Adger, W. N. (2004): Does adaptive management of natural resources enhance resilience to climate change? - Ecology and Society 9(2): 1-14. https://doi.org/10.5751/ES-00667-090210.

[64] UNDP (2008): Human Development Reports 2007/8. - In: Fighting Climate Change: Human Solidarity in a Divided World. United Nations Development Programme. Kluwer Academic Publishers, Dordrecht, pp. 1-115.

[65] United Nations (2013): United Nations Plan of Action on Disaster Risk Reduction for Resilience. - United Nations System, Chief Executives Board for Coordination, USA, pp-6-8.

[66] Vandenbroucke, J. P., Von Elm, E., Altman, D. G., Gøtzsche, P. C., Mulrow, C. D., Pocock, S. J., ... Egger, M. (2007): Strengthening the reporting of observational studies in epidemiology (STROBE): explanation and elaboration. - PLoS Medicine 4(10): 1628-1654. https://doi.org/10.1371/journal.pmed.0040297.

[67] Vogel, C., Moser, S. C., Kasperson, R. E., Dabelko, G. D. (2007): Linking vulnerability, adaptation, and resilience science to practice: pathways, players, and partnerships. - Global Environmental Change 17(3-4): 349-364. https://doi.org/10.1016/j.gloenvcha.2007.05.002.

[68] Walker, B., Salt, D. (2012): Practicing Resilience in Different Ways. - In: Walker, B., Salt, D. (eds.) Resilience Practice. Island Press/Center for Resource Economics, Washington, DC, pp. 145-167. https://doi.org/10.5822/978-1-61091-231-0_9.

[69] Weldegebriel, Z. B., Amphune, B. E. (2017): Livelihood resilience in the face of recurring floods: an empirical evidence from Northwest Ethiopia. - Geoenvironmental Disasters 4(1): 10. https://doi.org/10.1186/s40677-017-0074-0.

[70] Wilson, N. J. (2014): The politics of adaptation: subsistence livelihoods and vulnerability to climate change in the Koyukon Athabascan Village of Ruby, Alaska. Human Ecology 42(1): 87-101. https://doi.org/10.1007/s10745-013-9619-3.

[71] Zebrowski, C. (2013): The nature of resilience. - Resilience 1(3): 159-173. https://doi.org/10.1080/21693293.2013.804672. 


\section{APPENDIX}

\section{Appendix A}

The following search strategies have been followed

\begin{tabular}{|c|c|}
\hline Web of science: & $\mathrm{TS}=($ resilien $*$ AND vul $)$ \\
\hline Engineering village: & resilience AND vulnerability ---- > \\
\hline Scopus: & $\begin{array}{l}\text { ( TITLE-ABS-KEY ( resilience AND vulnerability ) ) AND ( livelihood AND resilience } \\
\text { ) AND ( LIMIT-TO ( DOCTYPE , "ar" ) OR LIMIT-TO ( DOCTYPE , "cp") OR } \\
\text { LIMIT-TO ( DOCTYPE, "ch") OR LIMIT-TO ( DOCTYPE, "ip" ) OR LIMIT-TO ( } \\
\text { DOCTYPE, "bk") ) AND ( LIMIT-TO ( SUBJAREA, "SOCI") ) AND ( LIMIT-TO ( } \\
\text { LANGUAGE, "English") ) }\end{array}$ \\
\hline
\end{tabular}

\section{Appendix B}

The following articles have been selected for the systematic literature review due to more relevancy

\begin{tabular}{|c|c|c|c|c|}
\hline SI no. & Researcher & Title & Method & Sources/journal \\
\hline 1 & Adger (1999) & $\begin{array}{l}\text { Social Vulnerability to Climate Change } \\
\text { and Extremes in Coastal Vietnam }\end{array}$ & Quantitative & World Development \\
\hline 2 & Kleine et al. (2003) & $\begin{array}{l}\text { Resilience to natural hazards: How } \\
\text { useful is this concept? }\end{array}$ & $\begin{array}{l}\text { Critical } \\
\text { review }\end{array}$ & Environmental Hazards \\
\hline 3 & Adger (2005) & $\begin{array}{c}\text { Social-Ecological Resilience to Coastal } \\
\text { Disasters }\end{array}$ & Quantitative & Science \\
\hline 4 & Adger (2006) & Vulnerability & Quantitative & Global Environmental Change \\
\hline 5 & $\begin{array}{l}\text { Thomalla et al. } \\
\text { (2006) }\end{array}$ & $\begin{array}{c}\text { Reducing hazard vulnerability: towards a } \\
\text { common approach between disaster risk } \\
\text { reduction and climate adaptation }\end{array}$ & Quantitative & Disasters \\
\hline 6 & $\begin{array}{c}\text { Earvolino-Ramirez } \\
\text { (2007) }\end{array}$ & Resilience: A Concept Analysis & $\begin{array}{l}\text { Critical } \\
\text { review }\end{array}$ & Nursing Forum \\
\hline 7 & Vogel et al. (2007) & $\begin{array}{l}\text { Linking vulnerability, adaptation, and } \\
\text { resilience science to practice: Pathways, } \\
\text { players, and partnerships }\end{array}$ & Quantitative & Global Environmental Change \\
\hline 8 & Paavola (2008) & $\begin{array}{l}\text { Livelihoods, vulnerability and adaptation } \\
\text { to climate change in Morogoro, Tanzania }\end{array}$ & Quantitative & Environmental Science Policy \\
\hline 9 & Gwimbi (2009) & $\begin{array}{c}\text { Linking rural community livelihoods to } \\
\text { resilience building in flood risk reduction } \\
\text { in Zimbabwe }\end{array}$ & Quantitative & $\begin{array}{c}\text { Jamba: Journal of Disaster } \\
\text { Risk Studies }\end{array}$ \\
\hline 10 & Alinovi et al. (2010) & $\begin{array}{c}\text { Measuring Household Resilience to Food } \\
\text { Insecurity: Application to Palestinian } \\
\text { Households }\end{array}$ & Quantitative & Agricultural Survey Methods \\
\hline 11 & Gaillard (2010) & $\begin{array}{c}\text { Vulnerability, capacity and resilience: } \\
\text { Perspectives for climate and } \\
\text { development policy }\end{array}$ & Quantitative & $\begin{array}{c}\text { Journal of International } \\
\text { Development }\end{array}$ \\
\hline 12 & $\begin{array}{l}\text { Jorgenson et al. } \\
\quad(2010)\end{array}$ & $\begin{array}{l}\text { Resilience and vulnerability of } \\
\text { permafrost to climate change }\end{array}$ & Quantitative & $\begin{array}{l}\text { Canadian Journal of Forest } \\
\text { Research }\end{array}$ \\
\hline 13 & Scholz et al. (2012) & $\begin{array}{l}\text { Risk, vulnerability, robustness, and } \\
\text { resilience from a decision-theoretic } \\
\text { perspective }\end{array}$ & Quantitative & Journal of Risk Research \\
\hline 14 & Can et al. (2013) & $\begin{array}{c}\text { Application of Livelihood Vulnerability } \\
\text { Index to Assess Risks from Flood } \\
\text { Vulnerability and Climate Variability- } \\
\text { A Case Study in the Mekong Delta of } \\
\text { Vietnam }\end{array}$ & Quantitative & $\begin{array}{l}\text { Journal of Environmental } \\
\text { Science and Engineering }\end{array}$ \\
\hline
\end{tabular}




\begin{tabular}{|c|c|c|c|c|}
\hline 15 & Ekblom (2012) & $\begin{array}{l}\text { Livelihood Security, Vulnerability and } \\
\text { Resilience: A Historical Analysis of } \\
\text { Chibuene, Southern Mozambique }\end{array}$ & $\begin{array}{l}\text { Critical } \\
\text { review }\end{array}$ & Ambio \\
\hline 16 & Zebrowski (2013) & The nature of resilience & $\begin{array}{l}\text { Critical } \\
\text { review }\end{array}$ & Resilience \\
\hline 17 & $\begin{array}{l}\text { Ajibade et al. } \\
\quad(2013)\end{array}$ & $\begin{array}{c}\text { Urban flooding in Lagos, Nigeria: } \\
\text { Patterns of vulnerability and resilience } \\
\text { among women }\end{array}$ & Quantitative & Global Environmental Change \\
\hline 18 & Fatemi et al. (2017) & $\begin{array}{c}\text { Social vulnerability indicators in } \\
\text { disasters: Findings from a systematic } \\
\text { review }\end{array}$ & Qualitative & $\begin{array}{l}\text { International Journal of } \\
\text { Disaster Risk Reduction }\end{array}$ \\
\hline 19 & Abid et al. (2016) & $\begin{array}{c}\text { Climate change vulnerability, adaptation } \\
\text { and risk perceptions at farm level in } \\
\text { Punjab, Pakistan }\end{array}$ & Quantitative & $\begin{array}{l}\text { Science of The Total } \\
\text { Environment }\end{array}$ \\
\hline 20 & Tanner et al. (2015) & $\begin{array}{l}\text { Livelihood resilience in the face of } \\
\text { climate change }\end{array}$ & $\begin{array}{l}\text { Critical } \\
\text { review }\end{array}$ & Nature Climate Change \\
\hline 21 & Lee (2014) & $\begin{array}{l}\text { Social vulnerability indicators as a } \\
\text { sustainable planning tool }\end{array}$ & Quantitative & $\begin{array}{l}\text { Environmental Impact } \\
\text { Assessment Review }\end{array}$ \\
\hline 22 & Pandey et al. (2017) & $\begin{array}{c}\text { Sustainable livelihood framework-based } \\
\text { indicators for assessing climate change } \\
\text { vulnerability and adaptation for } \\
\text { Himalayan communities }\end{array}$ & Quantitative & Ecological Indicators \\
\hline 23 & Panthi et al. (2016) & $\begin{array}{l}\text { Livelihood vulnerability approach to } \\
\text { assessing climate change impacts on } \\
\text { mixed agro-livestock smallholders } \\
\text { around the Gandaki River Basin in Nepal }\end{array}$ & Quantitative & $\begin{array}{l}\text { Regional Environmental } \\
\text { Change }\end{array}$ \\
\hline 24 & Shaw et al. (2016) & Building Community Resiliency & Quantitative & $\begin{array}{c}\text { Urban Disasters and Resilience } \\
\text { in Asia } \\
\end{array}$ \\
\hline 25 & $\begin{array}{l}\text { Weldegebriel and } \\
\text { Amphune (2017) }\end{array}$ & $\begin{array}{l}\text { Livelihood resilience in the face of } \\
\text { recurring floods: an empirical evidence } \\
\text { from Northwest Ethiopia }\end{array}$ & Quantitative & Geoenvironmental Disasters, \\
\hline 26 & $\begin{array}{l}\text { Bhuiyan et al. } \\
\text { (2017) }\end{array}$ & $\begin{array}{c}\text { Exploring impacts and livelihood } \\
\text { vulnerability of riverbank erosion hazard } \\
\text { among rural household along the river } \\
\text { Padma of Bangladesh }\end{array}$ & Quantitative & $\begin{array}{l}\text { Environmental Systems } \\
\text { Research }\end{array}$ \\
\hline 27 & Alam et al. (2018) & $\begin{array}{l}\text { How do climate change and associated } \\
\text { hazards impact on the resilience of } \\
\text { riparian rural communities in } \\
\text { Bangladesh? Policy implications for } \\
\text { livelihood development }\end{array}$ & Quantitative & $\begin{array}{l}\text { Environmental Science and } \\
\text { Policy }\end{array}$ \\
\hline 28 & $\begin{array}{c}\text { Chaffin and Scown } \\
\text { (2018) }\end{array}$ & $\begin{array}{l}\text { Social-ecological resilience and } \\
\text { geomorphic systems }\end{array}$ & Quantitative & Geomorphology \\
\hline 29 & $\begin{array}{c}\text { Bhattacharjee and } \\
\text { Behera (2018) }\end{array}$ & $\begin{array}{l}\text { Determinants of household vulnerability } \\
\text { and adaptation to floods: Empirical } \\
\text { evidence from the Indian State of West } \\
\text { Bengal }\end{array}$ & Quantitative & $\begin{array}{l}\text { International Journal of } \\
\text { Disaster Risk Reduction }\end{array}$ \\
\hline
\end{tabular}

